\title{
Analysis Welfare Determinants of Poor Family in Makassar City on SDGS Perspective
}

\author{
Basri Bado ${ }^{1, *}$, Syamsu Alam², Dedy Rastrawan ${ }^{3}$ \\ ${ }^{1}$ Economics Development FEB Universitas Negeri Makassar \\ ${ }^{2}$ Economics Development FEB Universitas Negeri Makassar \\ ${ }^{3}$ Student of Economics Development FEB Universitas Negeri Makassar \\ ${ }^{*}$ Corresponding author.Email: basri.bado@unm.ac.id
}

\begin{abstract}
Welfare is a right for all people, but the problem of poverty results in a different degree of welfare for poor families. This study aims to analyze the determinants that affect the welfare of poor families in the city of Makassar with the research year 2020. As well as to determine the extent of the readiness of the city of Makassar in facing sustainable development. The method of analysis used is path analysis regression. The results showed that economic factors and political accessibility had a significant positive effect on subjective welfare as an intervening variable. Meanwhile, economic factors, political accessibility and subjective welfare have a significant effect on the welfare of the objective family. Subjective welfare as an intervening variable partially mediates, which means that the determinant factors tested can directly affect the welfare of the objective of the family or indirectly through subjective welfare.
\end{abstract}

\section{Keywords: Objective Well-being, Subjective Wellbeing, Intervening Variables, Path Analysis}

\section{INTRODUCTION}

One example of poor development planning in urban areas today is poverty. This is evidenced by the sectoral planning carried out by each region, giving rise to migration patterns and flows that give rise to people's perceptions of moving people to improve their quality of life. Discussing poverty is not an easy matter considering that this country is still in the developing stage to catch up in development, considering that Indonesia is an archipelagic country so that it has become a challenge for Indonesia itself to determine priorities in carrying out pro-community development, especially those who are classified as poor.

To harmonize good development and answer the demands of world leadership in overcoming poverty, inequality, and climate change in the form of concrete actions, an international goal was agreed upon by 193 countries in August 2015, the goal is called the Sustainable Development Goals (SDGs). The goals have been integrated by several indicators so that these goals are more directed to a balance between environmental, social, and economic which is supported by all agencies, both government, private and non-government institutions [1].

Welfare is the right of all people regardless of the social status of the community. In the current perspective, welfare is widely known only in terms of material, knowledge, and health indexes. but actually welfare must be viewed in a multidimensional way so that in measuring welfare it can be more focused. Regarding the factors that affect the welfare of the community in Tembarak District, Tamanggung Regency with the results of the study grouping the factors into 3 groups, namely family factors, social status factors, family productivity factors [2]. These three factors are known to have a positive and significant effect on people's welfare

Community welfare can be hampered if the social strength of the family is weak so that welfare can be focused on the potential or human ability to improve the welfare of the community and family [3]. The strategy to 
solve this is to reduce the powerlessness of the family and expand accessibility. This powerlessness can be developed by the family through their social capital, while family accessibility can be facilitated, political freedom, economic opportunity, and social opportunities (education, health, etc.), transparency, and the existence of a social safety net.

In this case Witya [4] makes a strategy in measuring community poverty by measuring the level of objective and subjective welfare which is influenced by the external environment such as economic, social, political, and supporting facilities and services. Of course this is in accordance with Sen's statement which emphasizes poverty on family freedom in society.

The study of subjective well-being associated with welfare in this case capital ownership was first developed [5]. In his research found that an increase in income is not able to increase a person's welfare (happiness). Absolute income is not an important factor in determining subjective well-being, but relative income. Indeed, subjective well-being is strongly influenced by economic factors and the accessibility given to a person. Where indirectly when basic needs can be met and wealth is increasing, the subjective well-being of individuals can increase.

\section{LITERATURE REVIEW}

The existence of differences in welfare from the rich and poor is one indicator in seeing poverty. According to Retherford, R.D . and Choe, M.K [6], defining poverty is a form of welfare of the poor, regardless of the reduced welfare of the rich. From the welfare of the poor, lack of access here means a person's lack of income. The level of welfare can be interpreted as the ability to access available resources (goods consumed). The ability to access available resources can be measured by the amount of a person's income or expenses.

The problem of poverty can be solved when in a country there is a substantial democracy. Where this substantive democracy requires the power and sovereignty of the people in all aspects of the field, so that the community is able to optimize its potential which will have an impact on contributing to the common welfare. Thus, poverty in a country can be overcome based on the power of the people who are empowered and live it without any restrictions on political and other accessibility. However, this theory only applies to persons with freedom as an instrument and a development goal. According to Witya [7], stating the rejection on the basis of the theory of freedom of the cent is first, freedom is an obstacle to economic development, second, for humans the fulfillment of economic needs is more important than political freedom,

The theory of poverty from year to year will experience changes in its meaning and goals, so a study is needed to examine the concept of poverty that can keep up with the times. Poverty is a situation where a person or household has difficulty meeting basic needs, while the supporting environment does not provide opportunities to improve welfare on an ongoing basis or to get out of vulnerability [1]. Based on several indicators from BPS, BKKBN, UNPD, it can be seen that 3 conditions can be monitored to see the poverty faced by households, namely: 1) Subjective well-being, 2) Core Welfare, and 3) Supporting environment (context).

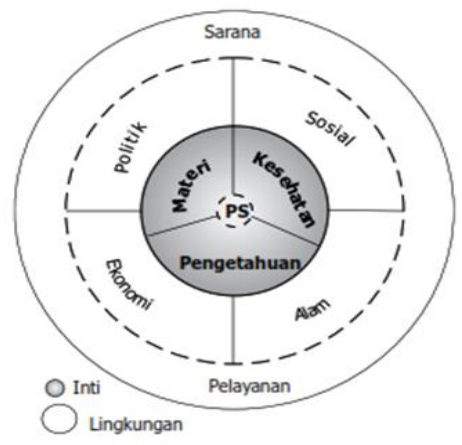

Figure 1. Welfare Model

(Source: Ade Cahyat et al. 2007)

Hypothesis

$\mathrm{H} 1$ = It is suspected that economic factors and political accessibility have a direct and significant positive effect on the subjective welfare of families in Makassar City.

$\mathrm{H} 2=$ It is suspected that economic factors, political accessibility, and subjective welfare have a direct and significant positive effect on the welfare of the nuclear family in Makassar City.

$\mathrm{H} 3=$ It is suspected that economic factors and political accessibility have an indirect and significant positive effect on the welfare of the nuclear family through subjective welfare in Makassar City.

\section{METHOD}

The type of data used in this study is primary data obtained directly from the object of research, namely the head of the household or someone who knows the data needed. Besides that, it is also possible that secondary data is needed in the form of population census results derived from several census results documents that have been carried out by institutions such as NonGovernmental Organizations (NGOs), BKKBN, and the Makassar City Social Service.

The researcher formulates the problem in the research area so that the population determination in this study can be formulated as all households in $15 \mathrm{sub}$ districts in the city of Makassar including all households 
classified in the pre-prosperous family stage. Furthermore, the technique of determining the sample using purposive sampling technique in this case the researcher takes the subject not based on strata, random or area but the researcher's own goals. From the background of the problem, the researcher suspects the urgency of the problem so that the researcher formulates pre-prosperous families in the Ujung Tanah, Tamalate, and Biringkanaya sub-districts of Makassar as the research sample area.

To make it easier to summarize all respondent data and to test whether the data is good or not, several stages are used, namely:

a. Descriptive Statistics,

b. Normality Test,

$$
K D: 1,36 \frac{\sqrt{n_{1}+n_{2}}}{n_{1} n_{2}}
$$

Information:

$$
\begin{aligned}
& \mathrm{KD}=\text { number of Kolmogorov-Smirnovs sought } \\
& \mathrm{n}_{1}=\text { number of samples obtained } \\
& \mathrm{n}_{2}=\text { expected number of samples }
\end{aligned}
$$

c. Reliability Test $\boldsymbol{r}_{i i}=\left[\frac{\boldsymbol{k}}{(\boldsymbol{k}-\mathbf{1})}\right]\left[\mathbf{1}-\frac{\sum \boldsymbol{\sigma}_{b}^{2}}{\sigma_{t}^{2}}\right]$ Information:

$$
\begin{array}{ll}
\text { rii } & =\text { Instrument reliability } \\
k & =\text { Number of questionnaire questions } \\
\sum \sigma_{b}^{2} & =\text { Number of variants } \\
\sigma_{t}^{2} & =\text { total variance }
\end{array}
$$

d. Validity test.

$$
r_{x y}=\frac{N \sum x y-\left(\sum x\right)\left(\sum y\right)}{\sqrt{\left[N \sum x^{2}-\left(\sum x\right)^{2}\right]\left[N \sum y^{2}-\left(\sum y\right)^{2}\right]}}
$$

Information:

$$
\begin{aligned}
& r_{x y} \quad=\text { Correlation Coefficient } \\
& N \quad=\text { Number of samples } \\
& \sum x=\text { Number of item scores } \\
& \sum y=\text { Total score }
\end{aligned}
$$

$\sum x y=$ The number of item scores multiplied by total score

$\sum x^{2}=$ Sum of squares of item scores

$\sum y^{2}=$ Sum of squares of total score

\section{e. Lnearity Test}

f. Multicollinearity test

\section{g. Heteroscedasticity test}

After the overall classification of data and the tests used meet the requirements, a path analysis will be carried out. Path analysis method is a technique to analyze the causal relationship that occurs in multiple regression if the independent variables affect directly or indirectly which have been mediated [7]. To make it easier to understand the direct relationship, researchers classify into 2 structural equations or substructures:

1. Structural Equation I

$$
K S=\beta_{X_{1} M} F E+\beta_{X_{2} M} A P++\varepsilon
$$

2. Structural Equation II

$$
K I=\beta_{X_{1} Y} F E+\beta_{X_{2} Y} A P+\beta_{M Y} K S+\varepsilon
$$

While the indirect relationship can be described with the following picture:

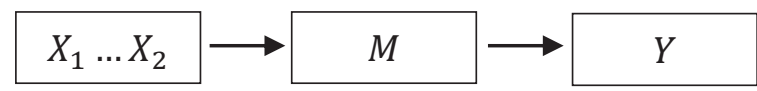

To test the mediating variable (intervening) it is necessary to test using the Sobel test. A variable is called mediating if the variable influences the relationship between the predictor (independent) and criterion (dependent) variables. The mediation model has a hypothesis that the independent variable affects the mediator variable, which in turn affects the dependent variable. Mediation (Perfect Mediation) occurs when there is no effect of the independent variable to the dependent if the mediator variable is included in the equation.

\section{DISCUSSION}

Effect of human development index, education, health and unemployment rate on economic growth in 2009-2018 period can be seen from multiple regression analysis. In this study, the authors use hypothesis testing, namely simultaneous test and partial test..

\subsection{Simultaneous Testing (F Test)}

Table 1. Interview Result

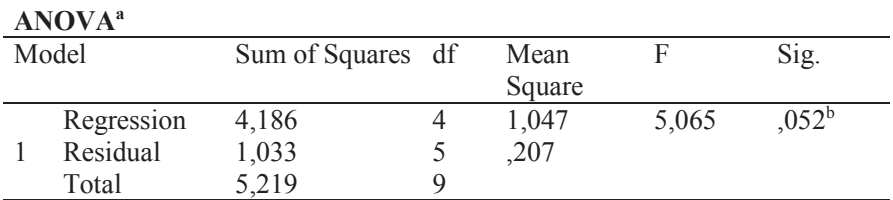

a. Dependent Variable: economic growth

b. Predictors: (Constant), human development index, Education, health, unemployment

In the previous table it can be seen where the significant value of $F$ is 0.052 and the calculated $F$ is 5.065. The value of $F$ table based on statistics is 4.76 . Thus, it can be concluded that $\mathrm{F}$ is significant $0.052<=$ 0.005 and F count: $5.065>$ ftable: 4.76 , so it can be concluded that the variables of education, 
unemployment, health level, and The human development index turns out to have a significant effect on economic development.

\subsection{Partial Testing ( $t$ Test)}

Table 2. Interview Result

\begin{tabular}{|c|c|c|c|c|c|c|}
\hline \multicolumn{7}{|c|}{ Coefficients $^{\mathrm{a}}$} \\
\hline \multirow{2}{*}{\multicolumn{2}{|c|}{ Model }} & \multicolumn{2}{|c|}{$\begin{array}{l}\text { Unstandardized } \\
\text { Coefficients }\end{array}$} & \multirow{2}{*}{$\begin{array}{l}\text { Standardized } \\
\text { Coefficients } \\
\text { Beta }\end{array}$} & \multirow[t]{2}{*}{$\mathrm{t}$} & \multirow[t]{2}{*}{ Sig. } \\
\hline & & B & $\begin{array}{l}\text { Std. } \\
\text { Error }\end{array}$ & & & \\
\hline \multirow{5}{*}{1} & $\begin{array}{l}\text { (Constan } \\
\text { t) }\end{array}$ & 69,860 & 39,172 & & 1,783 & , 135 \\
\hline & $\begin{array}{l}\text { Educatio } \\
\mathrm{n}\end{array}$ &,- 085 &, 060 &,- 832 & $-1,422$ & ,214 \\
\hline & $\begin{array}{l}\text { Unemploy } \\
\text { ment }\end{array}$ & ,217 & ,417 & ,485 &, 520 & ,625 \\
\hline & $\begin{array}{l}\text { Health } \\
\text { Level }\end{array}$ &,- 400 &, 531 &,- 439 &,- 753 & ,485 \\
\hline & $\begin{array}{l}\text { Human } \\
\text { Developm } \\
\text { ent Index }\end{array}$ &,- 404 &, 105 &,- 881 & $-3,864$ &, 012 \\
\hline
\end{tabular}

a. Dependent Variable: economic growth

1) The constant value (a) has a constant value of 69.860 which means that if there is no influence of the variables of education, unemployment, health levels, and the human development index which are considered constant, the variable of economic growth is 69.860 in South Sulawesi during the 2009-2018 period.

2) The significant value for the education variable is 0.214 where education is higher than 0.05 , therefore a conclusion can be drawn where economic growth is not partially affected by unemployment

3) The significant value for the unemployment variable is 0.625 , which means that unemployment is greater than 0.05 , so it can be concluded that unemployment has no partial effect on economic growth.

4) The significant value for the health level variable is 0.485 that the level of health is higher than 0.05 , which can be drawn a conclusion, namely the health level has no partial effect on economic growth.

5) The significant value for the human development index variable is 0.012 that the human development index is below 0.05 , therefore we can draw a conclusion where the human development index has a significant effect on economic growth.

From the results of data analysis and hypothesis testing that has been carried out in this study, it was found that the education variable has a significance value of 0.214 is higher than 0.05 , therefore we are able to draw a conclusion where education does not have an influence on economic growth. The t-count results in the previous table show -1.422 with a t-table of 2.447 . it shows where $\mathrm{t}$-count is smaller than $\mathrm{t}$-table, which indicates that the education variable does not have a significant effect on economic growth. The explanation above proves that education shows a decline in economic growth every year.

The unemployment variable has a significance value of 0.625 which is greater than 0.05 , therefore it can be concluded that economic growth has no effect on the unemployment variable.. The result of t-count shows the value is 0.520 and t-table, which means t-count is smaller than t-table, which indicates that the unemployment variable does not have a significant effect on economic growth. The explanation above proves that unemployment shows a decline in economic growth every year.

The health level variable has a value of 0.625 which is higher than 0.05 , therefore it can be drawn a conclusion that economic growth cannot be influenced by the health level variable. The results of the t-count show a value of -0.753 and the t-table, which means $t$ count is smaller than $\mathrm{t}$ table which shows that economic growth cannot be influenced by the health level variable. The explanation above proves that the level of health shows a decline in economic growth every year.

The human development index variable has a value of 0.625 which is higher than 0.05 , therefore we can conclude that the unemployment variable does not has had an effect on economic development. In the results of the t-count shows a value of $-3,684$ and the t-table. This means that the t-count is lower than the t-table, therefore we can conclude that the human development index variable has a significant effect on economic growth. This explanation proves that if the human development index has increased, then economic growth will have an increase. This fits the view described by Tsamadias, CP. [3] here economic development and economic growth have a two-way correlation, economic growth will increase human development. Also argue that the fairly rapid growth of human development will indirectly have a positive influence on economic growth [6]. However, there are several concepts that explain where economic growth has a dual quality in human development, in the practical process there are several factors that can influence this dual quality. In addition to the factors that influence the dual causation, there are also factors that are able to strengthen which are related to economic growth and human development. This is in accordance with what was stated by Kuswardinah, Asih [5] where the reinforcing factors between economic growth and human development are appropriate economic policies, economic structure, income distribution, asset distribution, high investment, and social capital. If you want to achieve an increase in the quality of human resources, you can get it if you go through several factors 
in determining the quality of resources, which has been previously studied by research of Hanusek, E., and L. Wößmann, [8] where expanding technical and scientific sources of knowledge can provide an increase in productivity labor and other inputs in production activities. This will have a good impact and increase the value of education and make job training activities capable of forming excellent human capital. Also have the opinion that when a person becomes healthier, has a good education and has good nutrition, this will contribute to economic improvement and will indirectly lead to increased productivity [8]. This shows where economic development can be influenced by the human development index of South Sulawesi Province, this results in an increase in the quality of human resources in an area that has a bearing on the quality of the human development index which is the main capital in economic development and can be increased to become more productive. good again.

\section{CONCLUSION}

a. In accordance with the previous data analysis and the discussion that has been carried out, a conclusion is obtained, namely:

b. The results of the study show that the education variable does not have a significant effect on economic growth in South Sulawesi, meaning that if education increases, it will have an impact on decreasing economic growth.

c. The results show that the unemployment variable does not have an influence on economic development in South Sulawesi.

d. The results show that the health level variable does not have an influence on economic development in South Sulawesi.

e. The results show that the human development index variable has an influence on economic development in South Sulawesi.

\section{ACKNOWLEDGMENTS}

We thank the anonymous reviewers who have provided constructive suggestions for improving this article

\section{REFERENCES}

[1] Wahyu P.i. 2009. Analisis Faktoryang Mempengaruhi Kesejahteraan Masyarakat Kecamatan Tembarak Kabupaten Tamanggung. Skripsi. Tidak Diterbitkan. Fakultas Matematika dan Ilmu Pengetahuan Alam. Universitas Negeri Semarang.

[2] Baron, R.M. \& Kenny, D.A. 1986. The Moderator Mediator Variable Distinction in Social
Psychological Research: Conceptual, Strategic, and Statistical Considerations. Jurnal of personality and social psychology.

[3] Cahyat, A., Gönner, C. and Haug, M. 2007 Mengkaji Kemiskinan dan Kesejahteraan Rumah Tangga: Sebuah Panduan dengan Contoh dari Kutai Barat Indonesia. CIFOR, Bogor, Indonesia. 121p.

[4] Witya. (2009). Pembangunan sebagai kebebasan. https://bocahdoyanmakan.blogspot.com/2009/02/pe mbangunan-sebagai-kebebasan-pengantar.html. diakses pada 30-11-2019

[5] Dutt, Amitava Krishna, dan Benjamin Radcliff. 1989. Happiness, economics and politics: Towards multi-disciplinary approach. Edward Elgar Publishing, 1989.

[6] Retherford, R.D . and Choe, M.K . (1993) Statistical Models for Causal Analysis. John Wiley and Sons, New York.

[7] Kuswardinah, Asih. 2016. Determinan Pembentukan Keluarga Sejahteran Bagi Keluarga Miskin Pedesaan di Kabupaten Wonosobo yang Berbasis Industri Kreatif Pangan. Jurnal Pendidikan Vokasi 06(3): 248-258. Retrieved.from: http://journal.uny.ac.id/index.php/jp

[8] Pininta, Lisbeth. Bakce, Djaimi . \& Yusri, Jum'atri. 2018. Faktor-Faktor Determinan Tingkat Kesejahteraan Rumahtangga Pesertap Rogram Desa Mandiri Pangan Di Provinsi Riau. Jurnal Àgribisnis. 20(1):11-20. 10.31849/agr.v20i1.1493. Retrieved from:

https://www.researchgate.net/publication/32890548 7 FAKTOR-

FAKTOR DETERMINAN TINGKAT KESEJAH TERAAN RUMAHTANGGA PESERTAP ROG RAM DESA MANDIRI PANGAN DI PROVIN SI RIAU 